DOI https://doi.org/10.18551/rjoas.2018-06.49

\title{
ASSESSMENT OF SMALL-SCALE FISHERIES MANAGEMENT USING ECOSYSTEM APPROACH TO FISHERIES MANAGEMENT INDICATORS IN SAWU SEA MARINE NATIONAL PARK, INDONESIA
}

\author{
Ninef Jotham S.R. \\ School of Post-graduate, Bogor Agricultural University, Bogor, Indonesia
}

\begin{abstract}
Adrianto L., Dahuri R., Rahardjo M.F.
Department of Aquatic Resources Management, Faculty of Fisheries and Marine Sciences, Bogor Agricultural University, Bogor, Indonesia
\end{abstract}

\author{
Adhuri Dedi S. \\ Research Center for Society and Culture, Indonesian Institute of Sciences, Jakarta Indonesia \\ *E-mail: joninef@gmail.com
}

\begin{abstract}
Ecosystem approaches to fisheries management are considered as an effective alternative at managing sustainable small-scale fisheries and supporting conservation program in Sawu Sea Marine National Park (Sawu Sea MNP); therefore, impelementation of EAFM in Sawu Sea MNP requires a strategic way. This present work aimed to evaluate current status of smallscale fisheries management using EAFM indicators. The evaluation results are then used for establishing the development strategies of sustainable small-scale fisheries using ecosystem approach in Sawu Sea MNP. The study was conducted in Rote Ndao, which is a sub region of Tirosa-Batek, Sawu Sea MNP. Data collection and analysis was performed according to EAFM assessment covering 30 indicators grouped into 6 domains. Based on evaluation of EAFM indicators, the composite value of small-scale fisheries management in Sawu Sea MNP ranged from 30.0 to 63.6 with the average value of 52.4. The value indicated that the state of small-scale fisheries management in Sawu Sea MNP was observed at medium level. Based on assessment of each domain, the economical domain was at bad level, while other domains (fish resource, habitat and ecosystem, fishing technology, social and institutional) were found at medium level. These our findings suggested that small-scale fisheries management in Sawu Sea MNP has not been managed optimally based on sustainable principles in EAFM indicators. Further improvement is addressed to economical domain in order to develop the small-scale fisheries management in Sawu Sea MNP.
\end{abstract}

\section{KEY WORDS}

Sawu Sea Marine National Park, small-scale fisheries, development, economy.

Small-scale fisheries have played important role in supplying food and employment for coastal communities that rely on fish as a single natural commodity (Alfaro-Shigueto et al 2010), as well as providing major employment and protein source for most population worldwide (Hauzer et al 2013). On the other hand, the small-scale fisheries have faced problematic facts related to reduced catch and environmental degradation (Hauzer et al 2013), as well as over capacity (Pomeroy 2012). Therefore, small-scale fisheries need to be managed properly which aimes to achieve sustainable development (Hauzer et al 2013). Pomeroy (2012) stated that overcapacity in small-scale fisheries in Southeast Asia requires integrated approaches including resource restoration and conservation.

Currently, a fisheries management approach is developed to enhance the sustainability of fisheries resource utilization considering the effectiviness and precautionary. Since 2001, Food and Agriculture Organization (FAO) has introduced Ecosystem Approach to Fisheries Management (EAFM) (FAO 2003), which is an alternative approach to fisheries management that addresses fisheries as an ecosystem; thus, its management needs to cover all relevant 
aspects (Cristie et al 2007). Specifically, EAFM is defined as fisheries management that considers knowledge and uncertainties about components of ecosystem including living marine resources, habitats, human, and strives to balance various societal objectives (Pomeroy et al 2010). EAFM aimes to balance economical-social and ecological objectives in which both is included in EAFM indicators divided into two major aspects: ecology (fisheries resource, habitat, fishing technology) and social (institution, social, and economical activities) (Adrianto et al 2012; KKP RI 2013; NWG EAFM 2014). In the EAFM perspective, marine protected area is regarded as the most suitable instrument to overcome various emerging fisheries problems, i.e. conserving exploited fish stock and biodiversity as well as improving fish catch and other societal objectives (Batista et al 2011).

Managing fisheries based on ecosystem approach is considered as the right option in order to achieve small-scale fisheries management goals and strengthen Sawu Sea MNP comprehensively. EAFM implementation in this site requires adaptive and precautionary approach to obtain effectiveness and successfulness; thus, strategies to implement EAFM in Sawu Sea MNP are necessary. The strategy is established using specific and measurable indicators that can describe the performance of fishery management, which in turn, they serve as reference to create sustainable fisheries management using ecosytem approach.

This article aimed to assess the state of Sawu Sea MNP using EAFM indicators in which they were then used as basis to determine further strategies to achieve sustainable small-scale fisheries management using ecosystem approach.

\section{METHODS OF RESEARCH}

This study was performed in sub region Rote Ndao, Sawu Sea MNP, Province of East Nusa Tenggara. The study site is selected for a major reason, that the location showed the highest fishing activity as indicated by the highest number of fishers and fishing boats compared to other sub regions. Sampling location (villages) was determined based on the highest fishing activity including: Oenggai, Nggodimeda, Metina, Oelua, Nemberala, Oeseli, Batutua, Daiama and Nuse (Figure 1).

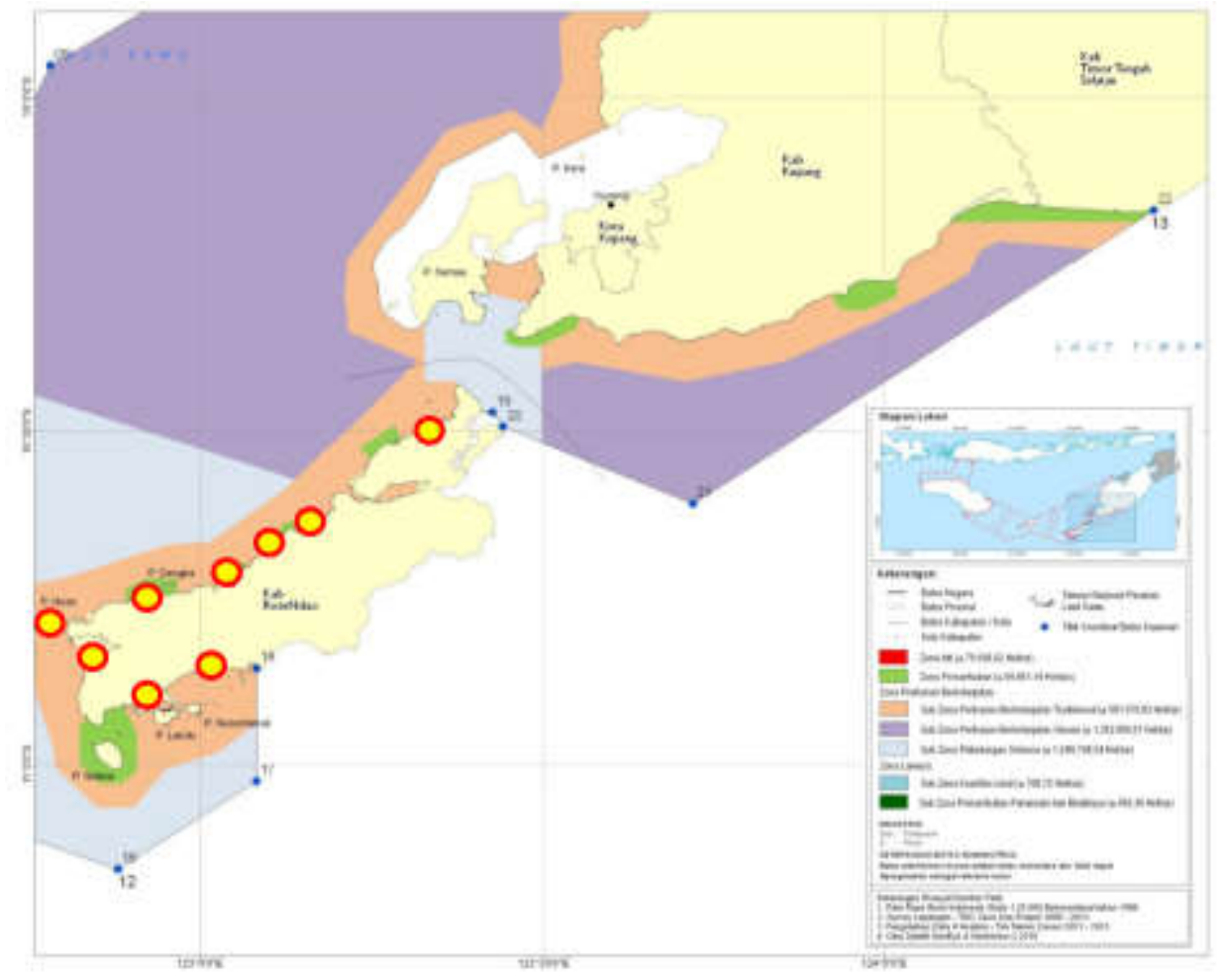

Figure 1 - Map of the chosen fishing community in the sub region Rote Ndao, Savu Sea MNP (Taken and modified from KKP RI 2013) 
Data were collected according to EAFM indicators of KKP RI (2013) using survey (interview, sampling, catch measurement) and observation method. The observation was held on small-scale fisheries activities while interviewing. In addition, incidental participative observation was also performed through observing fishing activities.

The state of small-scale fisheries in Sawu Sea MNP was analyzed using EAFM method (Adrianto et al 2012; KKP RI 2013; NWG EAFM 2014). In this study, 30 indicators divided into 6 domains (fish resources, habitat and ecosystem, fishing technology, economy, social, and institutional) were assessed. Each indicator may have different weight and criteria (KKP RI 2013; NWG EAFM) and is evaluated using flag model. The flag model technique is used using multi-criteria analysis (MCA) where a set of criteria was established as base for the performance analysis of the fishery management area through development of composite index (Adrianto et al 2012). The stages are described as follows:

- Selecting criteria for each indicator of EAFM aspects (habitat, fish resource, fishing technology, social, economy, and institutional) as described in Table 1;

- Assessing the performance of each indicator tested;

- Scoring each indicator performance (Likert score based ordinal 1, 2, 3);

- Determining the weight of each indicator;

- Determining composite index for each aspect using following function:

$$
C_{A} i=f\left(C_{A n} \ldots . . n=1,2,3 \ldots . . m\right)
$$

- Determining composite index for entire EAFM performace using following function:

$$
C-W P P=f(C A i \ldots \ldots i=1,2,3 \ldots \ldots . j ; j=6)
$$

\begin{tabular}{|c|c|c|}
\hline Domain & Indicator & Criteria \\
\hline \multirow[t]{7}{*}{ Fish resource } & 1. Raw CPUE & $\begin{array}{l}1=\text { decrease sharply (average decrease }>25 \% \text { per year); } \\
2=\text { decrease slightly (average decrease }<25 \% \text { per year); } \\
3=\text { stable or increase }\end{array}$ \\
\hline & 2. Fish size trend & $\begin{array}{l}1 \text { = average caught fish size is getting smaller; } \\
2 \text { = average caught fish size is stable; } \\
3 \text { = average caught fish size is getting bigger. }\end{array}$ \\
\hline & 3. Proportion of juvenile fish & $\begin{array}{l}1=\text { an awful lot of }(>60 \%) \\
2=\text { a lot }(30-60 \%) \\
3=\text { few }(<30 \%)\end{array}$ \\
\hline & $\begin{array}{l}\text { 4. Composition of caught } \\
\text { species }\end{array}$ & $\begin{array}{l}1=\text { proportion of target species is lower }(<15 \% \text { of total volume }) ; \\
2=\text { proportion of target and non-target species is equal }(16-30 \% \text { of total }) ; \\
3=\text { proportion of target species is higher }(>31 \% \text { of total volume }) .\end{array}$ \\
\hline & \multirow[t]{2}{*}{ 5. "Range Collapse" } & $\begin{array}{l}1=\text { more difficult, depending on target species } \\
2=\text { relatively constant, depending on target species } \\
3=\text { easier, depending on target species }\end{array}$ \\
\hline & & $\begin{array}{l}1 \text { = fishing ground is too far, depending on target species; } \\
2 \text { = fishing ground is far, depending on target species; } \\
3 \text { = fishing ground is fixed, depending on target species. }\end{array}$ \\
\hline & $\begin{array}{l}\text { 6. Species of ETP (Endangered, } \\
\text { Threatened and Protected) }\end{array}$ & $\begin{array}{l}1 \text { = caught but not released; } \\
2 \text { = caught, but released; } \\
3 \text { = no ETP species caught. }\end{array}$ \\
\hline \multirow[t]{4}{*}{$\begin{array}{l}\text { Habitat and } \\
\text { ecosytem }\end{array}$} & 1. Quality of waters & $\begin{array}{l}1 \text { = upper of environmental quality standard; } \\
2 \text { = same with environmental quality standard; } \\
3 \text { = under of environmental quality standard. }\end{array}$ \\
\hline & 2. Status of seagrass & $\begin{array}{l}1=\text { seagrass cover is lower, } \leq 30 \% \\
2=\text { seagrass cover is medium, }>30 \%-<60 \% \\
3=\text { seagrass cover is high, }>60 \% \\
1=\text { Biodiversity index is low }\left(H^{\prime}<3,2 \text { or } H^{\prime}<1\right) \\
2=\text { Biodiversity index is medium }\left(3,2<H^{\prime}<9,97 \text { or } 1<H^{\prime}<3\right) \\
3=\text { Biodiversity index is high }\left(H^{\prime}>9,97 \text { or } H^{\prime}>3\right)\end{array}$ \\
\hline & 3. Status of mangrove & $\begin{array}{l}1=\text { mangrove vegetation cover is low },<50 \% \\
2=\text { mangrove vegetation cover is medium, }>50 \%-<75 \% \\
3=\text { mengrove vegetation cover is high, }>75 \% \\
1=\text { density is low }(<1000 \text { tree/ha) } \\
2=\text { density is medium }(1000-1500 \text { tree/ha) } \\
3=\text { density is high }(>1500 \text { tree/ha) }\end{array}$ \\
\hline & 4. Status of coral reef & $1=$ live coral cover is low, $<25 \%$ \\
\hline
\end{tabular}

Table 1 - Domain, indicator and criteria for assessment of small-scale fisheries using EAFM analysis 


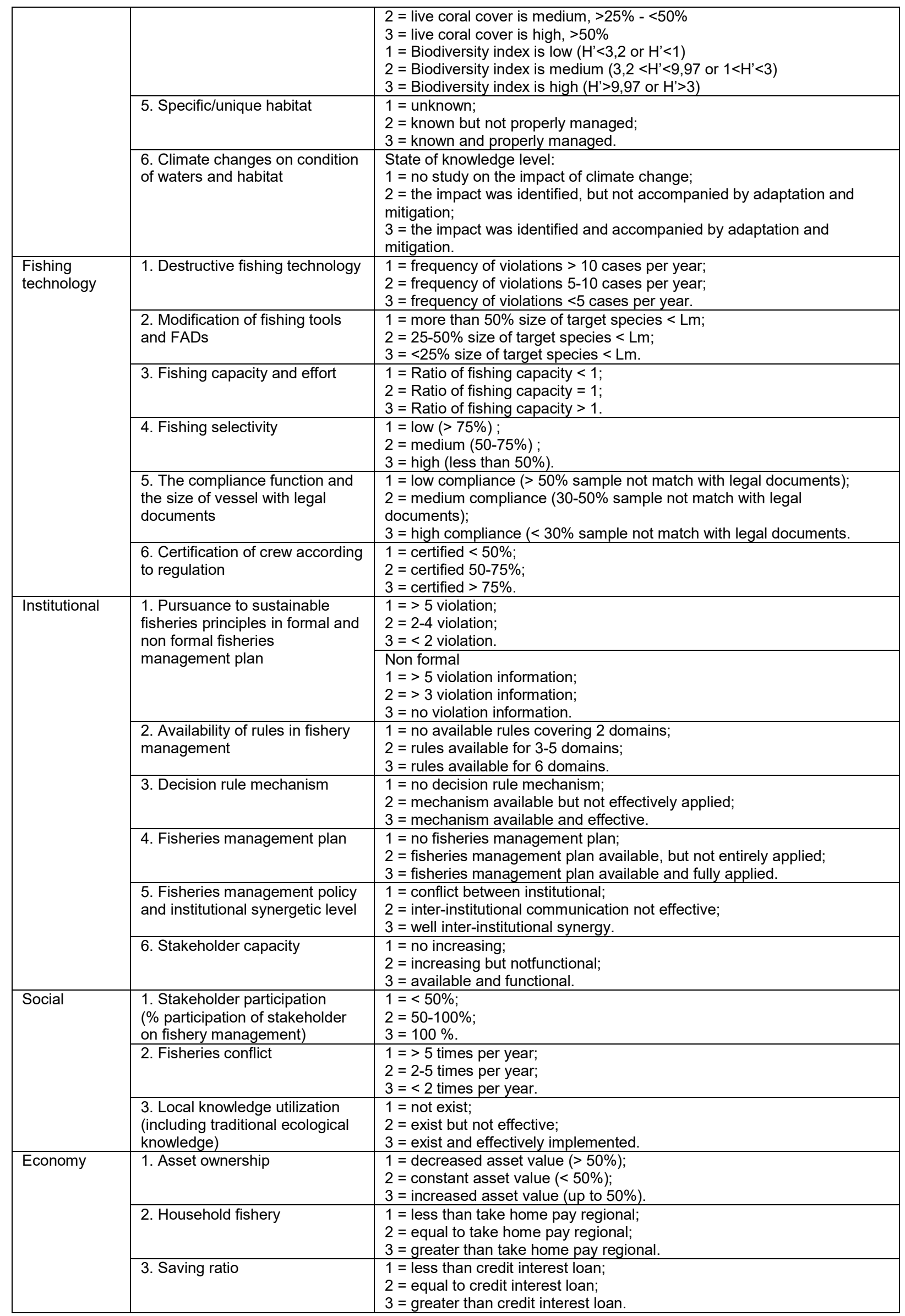

Source: KKP RI 2013. 
After assessing the state of small-scale fisheries in Sawu Sea MNP, the result was used as base for Kobe like Plot analysis to establish the required strategies for improvement of fisheries management.

\section{RESULTS AND DISCUSSION}

Domain of fish resource. The result indicates that total composite value of fish resource in small-scale fisheries of Sawu Sea MNP is 4351 with corrected composite value of 53.3 and average score of 1.83, which is classified as medium level (yellow). Assessment on each indicator shows that composition of caught species is at good category, while other indicators, i.e. raw CPUE, proportion of juvenile, and range collapse are in medium level. However, two remain indicators (fish size trend, species of ETP) are in bad category (Table 2). This indicates that the size of caught fish in this area tends to be smaller, and if this continues to happen, the fish stock in future will be reduced. Hence, a better management needs to conduct in order to increase the fish size. Additionally, the caught ETP species (Endangered Species, Threatened Species, and Protected) which is not released to its habitat indicates low awareness of fishers to the importance of ETP species protection for ecosystem and fish resource. The commonly captured ETP species includes green turtles, shark, and dolphin. The improvement in this domain is focused on the fish size trend and species of ETP.

Table 2 - Assessment of fish resource domain

\begin{tabular}{lccccccc}
\hline \multicolumn{1}{c}{ Fish resource } & $1^{*}$ & $2^{*}$ & $3^{*}$ & $4^{*}$ & $5^{*}$ & $6^{*}$ \\
\hline \multicolumn{1}{c}{ Results } & $\begin{array}{c}\text { Decrease } \\
\text { < 25\%/year }\end{array}$ & Getting smaller & $30-60 \%$ & $>30 \%$ & $\begin{array}{c}\text { Relatively } \\
\text { constant }\end{array}$ & $\begin{array}{c}\text { Captured and } \\
\text { not released }\end{array}$ \\
Score & 2 & 1 & 2 & 3 & 2 & 1 \\
Weight & 40 & 20 & 15 & 10 & 10 & 2 \\
Density score & 29 & 29 & 29 & 29 & 29 & 100 \\
Value & 2320 & 1 & 870 & 580 & 580 & 29 \\
\hline
\end{tabular}

Note: * 1) Raw CPUE, 2) fish size trend, 3) proportion of juvenile, 4) species composition, 5) range collapse, 6) species of ETP.

Domain of habitat and ecosystem. The assessment of EAFM indicators for domain of habitat and ecosystem in small-scale fisheries of Sawu Sea MNP shows that total composite value for this domain reaches 4351 with corrected composite value of 62.2 and average score of 2.0. The domain is classified as medium level (yellow). For indicator analysis, we found that quality of waters was at good condition, while ecosystem status of coral reefs, unique habitat, and climate change was at medium level. Unfortunately, ecosystem status of mangrove was recorded as bad level (Table 3). This result indicates that the main target for future improvement in this domain is addressed to mangrove ecosystem through rehabilitation program contributing to increase density of mangrove vegetation as well as enhancement of local awareness and supervision. The existence of mangrove ecosystem provides a fundamental role in providing habitats for various juvenils, crabs, shrimps, and mollusks.

Table 3 - Assessment of habitat and ecosystem domain

\begin{tabular}{|c|c|c|c|c|c|c|c|}
\hline $\begin{array}{l}\text { Habitat and } \\
\text { ecosystem }\end{array}$ & $1^{*}$ & $2^{*}$ & $3^{*}$ & $4^{*}$ & $5^{*}$ & $6^{*}$ & Total \\
\hline Results & $\begin{array}{c}\text { Under } \\
\text { environmental } \\
\text { quality standard }\end{array}$ & $\begin{array}{l}\text { VegetationCover } \\
<60 \%\end{array}$ & $\begin{array}{l}\text { Low } \\
\text { cover } \\
\text { and } \\
\text { density }\end{array}$ & $\begin{array}{c}\text { Cover and } \\
\text { diversity at } \\
\text { medium } \\
\text { level }\end{array}$ & $\begin{array}{c}\text { Known and } \\
\text { not well } \\
\text { managed }\end{array}$ & $\begin{array}{l}\text { Known and not } \\
\text { accompanied by } \\
\text { adaptation } \\
\text { strategies }\end{array}$ & \\
\hline Score & 3 & 2 & 1 & 2 & 2 & 2 & 2 \\
\hline Weight & 25 & 15 & 15 & 15 & 20 & 10 & 100 \\
\hline $\begin{array}{l}\text { Density } \\
\text { score }\end{array}$ & 29 & 29 & 29 & 29 & 29 & 29 & \\
\hline Value & 1933 & 870 & 1 & 870 & 1160 & 580 & 5414 \\
\hline
\end{tabular}

Note: * 1) quality of waters, 2) status of seagrass ecosystem, 3) status of mangrove ecosystem, 4) status of coral reef ecosystem, 5) unique habitat, 6) climate change. 
Domain of Fishing Technology. The results of EAFM assessment shows that total composite value for this domain is 4641 with corrected composite value of 53.3 and average score of 1.67. This domain is categorized as medium (yellow). For domain of fishing technology, no one of indicators is recored at good level, but all indicators are at medium and bad level (Table 4). The both indicators (fishing capacity and effort, crew certification) are at bad level; thus, they become the further target for improvement. There is clearly a need to overcome the weaknesses in this domain in order to escalate the ratio of fishing capacity and effort to be 1 or $>1$. Furthermore, the certification of fishing crew is also important to increase in order to enhance human resource capacity through training program and competency certification. Other efforts are required to alleviate the use of destructive fishing method, modification of fishing gears and unselective of fishing technology.

Table 4 - Assessment of fishing technology domain

\begin{tabular}{lccccccc}
\hline $\begin{array}{c}\text { Fishing } \\
\text { Technology }\end{array}$ & $1^{*}$ & $2^{*}$ & $3^{*}$ & $4^{*}$ & $5^{*}$ & $6^{*}$ & Total \\
\hline \multirow{1}{*}{ Results } & $\begin{array}{c}5-10 \text { cases } \\
\text { per year }\end{array}$ & $\begin{array}{c}25- \\
50 \%\end{array}$ & $\begin{array}{c}\text { Ratio of fishing } \\
\text { capacity }<1\end{array}$ & $\begin{array}{c}\text { Medium } \\
(50-75 \%)\end{array}$ & $\begin{array}{c}\text { Compliance } \\
30-50 \%\end{array}$ & $\begin{array}{c}\text { Certificate ownership } \\
<50 \%\end{array}$ \\
Score & 2 & 2 & 1 & 2 & 2 & 1 & 2 \\
Weight & 30 & 25 & 15 & 15 & 10 & 5 & 100 \\
Density score & 29 & 29 & 29 & 29 & 29 & 29 & 4641 \\
Value & 1740 & 1450 & 1 & 870 & 580 & 0 & 4604 \\
\hline
\end{tabular}

Note: * 1) destructive fishing, 2) modification of fishing gears, 3) fishing capacity and effort, 4) selectivity, 5) accompliance of boat function and size, 6) crew certification

Domain of Social. The results of EAFM assessment for social domain show that the total composite value is 4496 with corrected composite value of 51.7 and average score of 2.00 , which is classified as medium level (yellow). The indicator of fisheries conflict is observed at good level, but remaining indicators (local knowledge utilization, stakeholder participation) are at bad level (Table 5). This is clear that further improvement for social domain will be addressed mainly to stakeholder participation in fisheries management. The participation of stakeholder is highly influential in achieving better fisheries management.

Table 5 - Assessment of social domain

\begin{tabular}{|c|c|c|c|c|}
\hline Social & $1^{*}$ & $2^{*}$ & $3^{*}$ & Total \\
\hline Results & $<50 \%$ & $<2$ times/year & Exist but not effective & \\
\hline Score & 1 & 3 & 2 & 2 \\
\hline Weight & 40 & 35 & 25 & 100 \\
\hline Density score & 29 & 29 & 29 & \\
\hline Value & 1 & 3045 & 1450 & 4496 \\
\hline
\end{tabular}

Note: * 1) participation of stakeholder, 2) fisheries conflict, 3) local knowledge utilization.

Domain of Economy. The assessment on EAFM indicators for economy domain in small-scale fisheries of Sawu Sea MNP results in total composite value of 2612 with corrected composite value of 30.0 and average score of 1.33. Based on aggregate value, the domain is classified as bad level (red). Furthermore, no one of indicators tested is at good level. The indicator of asset ownership is found at medium level, while remaining indicators (saving ratio, household fishery income) are at bad level (Table 6). The further improvement is focused mostly on the escalation of income (equal to take home pay regional) and financial management of fishers that enable to increase their saving ratio.

Table 6 - Assessment of economy domain

\begin{tabular}{lcccc}
\hline \multicolumn{1}{c}{ Economy } & $1^{*}$ & $2^{*}$ & $3^{*}$ & Total \\
\hline Results & Fix asset value & Less than take home pay regional & Less than credit interest loan \\
Score & 2 & 1 & 1 & 1 \\
Weight & 45 & 30 & 25 & 100 \\
Density score & 29 & 29 & 29 & 2612 \\
Value & 2610 & 1 & 1 & 26 \\
\hline
\end{tabular}

Note: * 1) asset ownership, 2) household income, 3) saving ratio. 
Domain of Institutional. The assessment of EAFM indicators for institutional domain results in total composite value of 5534 with corrected composite value of 63.6 and average score of $2.23(\approx 2.00)$. The domain is categorized as medium level (yellow). The rule availability and fisheries management plan are indicators that possess bad level, while other indicators are at medium level (Table 7). The future improvement is majorily allocated for fishery management plan and other indicators which are at medium category. The fishery management plant must be present as operational standard for responsible fishery operation. In Sawu Sea MNP, document for management plan of the area has been composed, which also provides a general description of capture fisheries in Sawu Sea MNP, but the document that specifically regulates capture fisheries in the area has not been made.

Table 7 - Assessment of institutional domain

\begin{tabular}{|c|c|c|c|c|c|c|c|}
\hline Institutional & $1^{*}$ & $2^{*}$ & $3^{*}$ & $4^{*}$ & $5^{*}$ & $6^{*}$ & Total \\
\hline Results & $\begin{array}{c}2-4 \\
\text { times }\end{array}$ & $\begin{array}{c}\text { Regulation } \\
\text { available for } 6 \\
\text { domains }\end{array}$ & $\begin{array}{l}\text { Mechanism } \\
\text { available, but } \\
\text { ineffective }\end{array}$ & $\begin{array}{c}\text { No management } \\
\text { plan available }\end{array}$ & $\begin{array}{c}\text { Ineffective } \\
\text { communication }\end{array}$ & $\begin{array}{l}\text { Available but } \\
\text { not functional }\end{array}$ & \\
\hline Score & 2 & 3 & 2 & 1 & 2 & 2 & 2 \\
\hline Weight & 25 & 26 & 18 & 15 & 11 & 5 & 100 \\
\hline $\begin{array}{l}\text { Density } \\
\text { score }\end{array}$ & 29 & 29 & 29 & 29 & 29 & 29 & \\
\hline Value & 1450 & 2111 & 1044 & 1 & 638 & 290 & 5534 \\
\hline
\end{tabular}

Note: * 1) pursuance to sustainable fisheries principles, 2) availability of rules in fishery management, 3) decision rule mechanism, 4) fisheries management plan, 5) Fisheries management policy and institutional synergetic level, 6) stakeholder capacity.

Agregate Composite Value of EAFM. The result shows that total composite value for EAFM domains ranges from 2612 to 5534 with aggregate value of 4580 . The maximum composite value of EAFM domains is 8700 , assuming that all indicators have maxiumum score (3.00). The domain composite value is converted to build flag model, resulting in converted composite value of 30.0-63.6 with aggregate composite value of 52.4. The indicator score from each domain ranges from 1.33 to 2.23 with average score of 1.87 for all EAFM domains. Based on aggregate composite value and average indicator value for all EAFM domains (Table 8), we found that small-scale fisheries management in Sawu Sea MNP was categorized at medium level.

Table 8 - The aggregate composite value of EAFM assessment in small-scale fisheries in Sawu Sea MNP

\begin{tabular}{|c|c|c|c|c|c|}
\hline \multirow[b]{2}{*}{ Domain } & \multicolumn{2}{|c|}{ Value } & \multirow{2}{*}{ Composite value } & \multirow{2}{*}{ Indicator score } & \multirow[b]{2}{*}{ Status } \\
\hline & Score obtained & Maximum score & & & \\
\hline Fishery resource & 4351 & 8700 & 53,3 & 2,00 & Medium \\
\hline Habitat and ecosystem & 5414 & 8700 & 62,2 & 2,00 & Medium \\
\hline Fishing technology & 4641 & 8700 & 53,3 & 1,67 & Medium \\
\hline Social & 4496 & 8700 & 51,7 & 2,00 & Medium \\
\hline Economy & 2612 & 8700 & 30,0 & 1,33 & Bad \\
\hline Institutional & 5534 & 8700 & 63,6 & 2,23 & Medium \\
\hline Aggregate & 4580 & 8700 & 52,4 & 1,87 & Medium \\
\hline
\end{tabular}

The results indicate that economy domain shows a weak contribution in the small-scale fisheries management in Sawu Sea MNP. The major reason is that most indicators in economy domain are under reference point. To achieve better small-scale fisheries management in this study site, further improvement is focused primarily on the economy domain. Habitat and ecosystem as well as instutitional domain are at good level in comparison with others, which means that both has already met the expectation but still requires further improvement, as also observed for fishery resource, fishing technology, and social.

Strategies for improving fisheries management. EAFM implementation considers other aspects including policy planning, strategic planning, and operational management planning (Gracia and Cochrane 2005). In case of policy planning, base and ultimate objectives of EAFM implementation should be stated through integration of social-economy objectives with 
regarding environmental aspect and fishery resource. The decision in EAFM implementation consists of strategic and tactical decision (Gavaris 2009).

Fishery management aimes to obtain optimum and sustainable utilization, as well as to ensure the conservation of fishery resource. The main objective of sustainable fisheries management is to create welfare for fishers and associated fishery enterprises while considering the availability of resource. The sustainable fisheries management includes two major dimensions: ecology (fishery resource and habitat domain) and social-economy (fishing, social, economy, and institutional). The key point to accomplish sustainable fisheries management is a well-established governance since it enables to balance both ecology and social-economy dimension. To achieve this, the government must create fishery management plant that includes short, medium and long term action plans.

Figure 2 constitutes a Kobe Plot for improvement plan of small-scale fisheries in Sawu Sea MNP, which covers three stages of improvement plans: short term ( $0-5$ years), mid term (5-10 years) and long term (10-15 years). This represents the strategies for achieving better small-scale fisheries management in Sawu Sea MNP. The short term strategy include restoration strategy. Meanwhile, conservation management strategy and sustaining strategy are planned for mid term while conserving the existing condition. In mid term, the state of fishery management is targeted to achieve medium level (yellow) from bad level (red), and in turn achieving the highest level (green). In long term, the sustaining strategy is set while maintaining the existing condition. In this phase, the fisheries management is targeted at good condition (green).

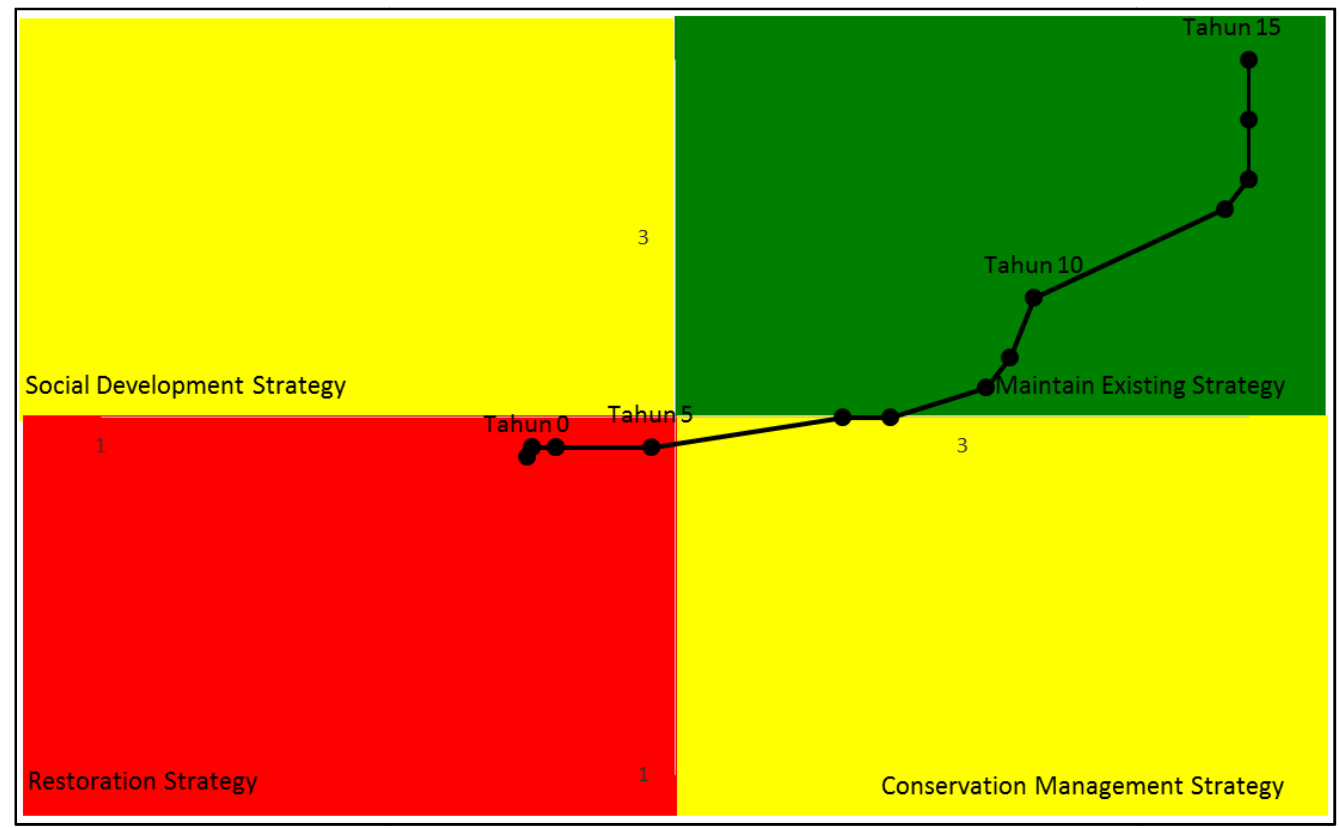

Figure 2 - Improvement plan of small-scale fisheries management using ecosystem approach

\section{CONCLUSION}

Performance of small-scale fisheries management in Sawu Sea MNP was evaluated, resulting that the management is at medium level. Economy domain, which is a part of ecosystem dimension, is categorized at bad level, while others are at medium level. There is a need to gradually improve small-scale fisheries management in Sawu Sea MNP, dividing into 3 steps: short term (0-5 years), mid term (5-10 years), and long term (10-15 years). The short term plan is impelemented through restoration strategy, while conservation management strategy and sustaining strategy are prepared for mid term. The long term improvement strategy is prepared through sustaining strategy while conserving the existing condition. 


\section{REFERENCES}

1. Adrianto, L., A. Habibi, A. Fahrudin, A. Azizy, H.A. Susanto, I. Musthfa, M.M. Kamal, S.H. Wisudo, dan Y. Wardiatno. 2012. Penilaian Indikator Pendekatan Ekosistem untuk Pengelolaan Perikanan. Kerjasama KKP RI, WWF Indonesia dan PKSPL IPB.

2. Alfaro-Shigueto, J., J. C. Mangel, M. Pajuelo, P. H. Dutton, J. A. Seminoff, dan B. J. Godley. 2010. Where small can have a large impact: Structure and characterization of small-scale fisheries in Peru. Fisheries Research 106 (2010) 8 - 17.

3. Batista, M. I., F. Baeta, M. J. Costa, H. N. Cabral. 2011. MPA as management tools for small-scale fisheries: The case study of Arrábida Marine Protected Area (Portugal). Ocean \& Coastal Management 54 (2011) 137-147

4. Cristie P, Fluharty DL, White AT, Eisma-Osorio L, Jatulan W. 2007. Assessing the feasibility of ecosystem-based fisheries management in tropical contexts. Marine Policy 31:239-250.

5. FAO. 2003. Ecosystem Approach to Fisheries. FAO Technical Paper.

6. Garcia SM. Cochrane KL. 2005. Ecosystem Approach to Fisheries: a review of implementation guidelines. ICES Journal of Marine Sciences 62:311-318.

7. Gavaris, S. 2009. Fisheries management planning and support for strategic and tactical decisions in an ecosystem approach context. Fisheries Research 100 (2009) 6-14.

8. Hauzer, M., P. Dearden, dan G. Murray. 2013. The effectiveness of community-based governance of small-scale fisheries, Ngazidja island, Comoros. Marine Policy 38 (2013) $346-354$.

9. KKP RI [Kementerian Kelautan dan Perikanan Republik Indonesia]. 2013. Modul Penilaian Pengelolaan Perikanan dengan Pendekatan Ekosistem (EAFM). National Working Group II EAFM, Direktorat Sumberdaya Ikan, Kementerian Kelautan dan Perikanan RI. 20 Juli 2013.

10. KKP RI [Kementerian Kelautan dan Perikanan Republik Indonesia]. 2013. Rencana Pengelolaan Taman Nasional Perairan Laut Sawu NTT tahun 2014 - 2034. BKKPN Kupang

11. NWG EAFM [National Working Group on Ecosystem Approach to Fisheries Management]. 2014. Modul Penilaian Indikator untuk Perikanan dengan Pendekatan Ekosistem. National Working Group on Ecosystem Approach to Fisheries Management. Direktorat Sumberdaya Ikan Kementerian Kelautan dan Perikanan Republik Indonesia.

12. Pomeroy, R., L. Garces, M. Pido, G. Silvestre. 2010. Ecosystem-based fisheries management in small-scale tropical marine fisheries: Emerging models of governance arrangements in the Philippines. Marine Policy 34 (2010) 298-308.

13. Pomeroy, R. S. 2012. Managing overcapacity in small-scale fisheries in Southeast Asia. Marine Policy 36 (2012) 520-527. 